\title{
Model Pembelajaran PAIKEM Berbantuan Media Audio Visual Terhadap Kompetensi Pengetahuan IPS
}

\author{
Pande Made Aditya Pramana \\ Program Studi Pendidikan Guru Sekolah Dasar Universitas Pendidikan Ganesha
}

\begin{abstract}
Abstrak
Tujuan Penelitian ini adalah untuk mengetahui pengaruh yang signifikan kompetensi pengetahuan IPS antara kelompok siswa yang dibelajarkan menggunakan model pembelajaran PAIKEM berantuan media Audio Visual dengan kelompok siswa yang dibelajarakan menggunakan pembelajaran konvensional pada siswa kelas IV SD. Jenis penelitian ini yang di lakukan adalah kuantitatif dengan disain eksperimen semu dan rancangannya non equivalen control group. Populasinya seluruh peserta didik kelas IV yang ada di Gugus Peliatan yang terdiri dari 4 kelas denga 2 sampel penelitian diambil dengan cara random sampling terdapat sampel eksperimen yang di terapkannya model PAIKEMberbantuanmeida audio-visual untuk kelas IV SD Negeri 4Peliatan sebanyak 34 peserta didik dan kelas IV SD Negeri 1 Peliatan sebanyak 36 peserta didik sebagai kelompok kontrol yang di belajarkan secara konvensional. Pengumpulan datanya mengunakan metode tes berupa tes objektif kompetensi pengetahuan IPS kedua kelompok. Terbukti dari nilai rerata GnS kelompok eksperimen yaitu 0,699 lebih dari kelompok kontrol yaitu 0,45 dan setelah analisis uji hipotesis diperoleh diperoleh $t_{h i t} 0,916>t_{t a b}(a=0,05,70)=1,99$, maka Ha diterima sehingga dapat disimpulkan bahwa model pembelajaran PAIKEM berbantuan Media audio-visual berpengaruh secara signifikan terhadap kompetensi pengetahuan IPS siswa kelas IV SD Negeri Gugus Peliatan Tahun Ajaran 2019/2020. Jadi dapat disimpulkan bahwa terdapat pengaruh yang signifikan model pembelajaran PAIKEM berbantuan media Audio Visual terhadap kompetensi pengetahuan IPS kelas IV SD. Berdasarkan hasil penelitian model ini dapat dijadikan bahan guru dalam memilih variasi saat proses pembelajaran dikarenakan sudah terbukti dapat meningkatkan kompetensi pengetahuan IPS.
\end{abstract}

\begin{abstract}
The purpose of this study was to determine the significant effect of social science knowledge competence between groups of students who were taught using the PAIKEM learning model with audio visual media and groups of students who were taught using conventional learning in fourth grade elementary school students. This type of research carried out is quantitative with quasi-experimental design and nonequivalent control group design. The population is all grade IV students in the Peliatan Cluster consisting of 4 classes with 2 research samples taken by random sampling. class IV SD Negeri 1 Peliatan as many as 36 students as a control group taught conventionally. The data collection uses the test method in the form of an objective test of the competence of social studies knowledge of the two groups. Evidenced by the mean value of GnS in the experimental group that is 0.699 more than the control group that is 0.45 and after the analysis of the hypothesis test obtained thit0.916> ttab $(a=0.05 .70)=1.99$, then Ha is accepted so it can be concluded that PAIKEM learning model assisted by audio-visual media significantly influences the competency of social science knowledge of the fourth grade students of SD Negeri Peliatan in the Academic Year 2019/2020. So it can be concluded that there is a significant influence of the PAIKEM learning model assisted by Audio Visual media on the competence of social science knowledge in grade IV elementary school. Based on the results of this research model can be used as teacher material in choosing variations during the learning process because it has been proven to be able to improve the competence of social science knowledge
\end{abstract}

\footnotetext{
* Corresponding author.

E-mail Addresses: - ajos.adit98@gmail.com (Pande Made Aditya Pramana)
} 


\section{PENDAHULUAN}

Pendidikan dalam arti luas yaitu setiap pendidikan maupun pengalaman yang terdapat dalam efek formatif pada pikiran, karakter maupun kemampuan pada fisik setiap individu. Wening (2012) mengemukakan bahwa pembangunan karakter yang berdasar nilai-nilai moral kemanusiaan sangat diperlukan setiap individu ataupun masyarakat melalui adanya proses pendidikan nilai. Sehingga pengembangan pendidikan karakter sangat diperlukan untuk mempersiapkan generasi bangsa yang memiliki rasa nasionalisme dan cinta tanah air yang tinggi.Pendidikan dapat menciptakan manusia yang berkualitas, serta mampu bersaing di era global seperti saat ini dan mampu menciptakan moral yang baik. Pendidikan terdiri dari beberapa komponen untuk mencapai itu semua, salah satunya kurikulum. Kurikulum memiliki peranan yang sangat penting dalam dunia pendidikan, kurikulum yang diterapkan saat ini adalah kurikulum 2013 (K-13) dengan pendekatan saintifik (5M). Kurikulum 2013 bertujuan untuk menghasilkan individu yang beriman kreatif, produktif, inovatif dan afektif serta diharapkan bisa berkontribusi pada kehidupan berbangsa dan bernegara. Penerapan kurikulum 2013 pada tingkat sekolah dasar menggunakan tematik integratif, yaitu mengaitkan beberapa mata pelajaran ke dalam sebuah tema. Sebuah tema terdiri dari tiga atau empat subtema, dalam subtema tersebut terdiri dari enam pembelajaran. Mata pelajaran seperti Bahasa Indonesia, PKn, IPS, IPS, Penjaskes, dan SBdP dipadukan dalam kegiatan-kegiatan pembelajaran dalam suatu tema, sehingga siswa tidak menyadari sedang mempelajari mata pelajaran tertentu. Dengan demikian mereka dapat memahami suatu konsep dengan utuh bukan hanya sebagai pengetahuan tetapi juga dapat diterapkan melalui kegiatan-kegiatan dalam pembelajaran.Di Sekolah Dasar pelajaran IPS adalah mata pelajaran yang mempelajari kehidupan sosial yang didasarkan pada bahan kajian geografi, ekonomi, sejarah, antropologi, sosiologi, dan tata negara. Dari pengertian tersebut, menunjukkan bahwa IPS merupakan perpaduan antara ilmu sosial dan kehidupan manusia yang didalamnya mencakup antropologi, ekonomi, geografi, sejarah, hukum, filsafat, ilmu politik, sosiologi, agama dan psikologi. Dimana tujuan utamanya adalah membantu mengembngkan kemampuan dan wawasan siswa yang menyeluruh (kompherensif) tentang berbagai aspek ilmu-ilmu sosial dan kemanusiaan (humaniora) Susanto (2014:139). Dapat dilihat dari beberapa penelitian yang dilakukan oleh Novi Widya (2017) tentang pengaruh model PAIKEM Berbantuan Video karena Terhadap Ketrampilan Menulis Siswa Kelas IV SD Gugus Letkol Wisnu Denpasar Utara Tahun Ajaran 2017/2018. Dengan Hasil Penelitian menunjukan terdapat perbedaan yang signifikan terhadap ketrampilan menulis antara siswa yang melaksanakan proses belajar menggunakan model pembelajaran PAIKEM bernabtuan audio-visual dengan siswa yang mengikuti pembelajaran konvensional. Hal tersebut dibuktikan dengan $t_{\text {hitung }}>t_{\text {tabel }}(4,517>2,000)$, serta terdapat perbedaan rata - rata kelompok yang dibelajarkan dengan menggunakan model yaitu 80,89 lebih dari rata - rata kelompok yang dibelajarkan menggunakan pembelajaran konvensional yaitu 72,85. Persamaan penelitian tersebut dengan penelitian ini terletak pada model pembelajaran yang diterapkan yaitu Model Pembelajaran PAIKEM. Adapun perbedaan penelitian ini terletak pada variabel terikat, populasi, dan tempat penelitiannya. Variabel terikat pada penelitian tersebut adalah hasil belajar PPKn, sedangkan variabel terikat pada penelitian ini adalah kompetensi pengetahuan IPS. Selain itu pada penelitian tersebut berbantuan Video, sedangkan pada penelitian ini berbantuan media-audio-visual(rina febriani, zaitul, 2019) .Namun pada kenyataannya banyak siswa yang belum menguasai pelajaran IPS dikarenakan pelajaran IPS yang dianggap sulit dan membosankan dengan cakupan materi yang luas dan padat.Berdasarkan hasil observasi dan wawancara yang dilaksanakan pada kelas IV dari tanggal 27 sampai 28 Oktober 2019 di seluruh SD Gugus Peliatan, didapatkan nilai kompetensi Penilaian Tengah Semester (PTS) IPS siswa masih ada yang belum mencapai nilai KKM. Dari 146 orang siswa sebanyak 67 \% belum mencapai nilai KKM, sedangkan sisanya sudah mencapai nilai KKM, selain itu juga ditemukan permasalahan kurangnya minat siswa dalam mengikuti pembelajaran IPS, siswa cenderung merasa cepat bosan pada saat pembelajaran IPS. Guru yang lebih banyak menggunakan metode ceramah dan tanya jawab selama kegiatan pembelajaran berlangsung. Kegiatan pembelajaran hanya berpusat pada guru. Selain itu, beberapa siswa kurang mampu mempergunakan lingkungan disekitarnya dengan baik untuk dipakai menjadi sumber belajar. Jika hal tersebut dibiarkan begitu saja, maka pembelajaran tentu tidak dapat berlangsung secara optimal. Berbagai faktor yang menyebabkan rendahnya kompetensi pengetahuan IPS siswa yaitu faktor internal dan faktor eksternal. Faktor internal merupakan faktor yang bersumber dari luar diri peserta didik yaitu keluarga, sekolah, dan masyarakat. Mencermati permasalahan belajar yang diuraikan di atas, dalam penelitian ini diterapkan sebuah inovasi baru yaitu pendekatan dalam pembelajaran yang dapat mempengaruhi kompetensi pengetahuan IPS siswa sehingga proses pembelajaran IPS berjalan secara optimal(Susanto, 2013). 
Keadaan seperti yang telah dipaparkan diatas jika terus dilakukan maka akan mempengaruhi hasil kompetensi pengetahuan siswa. Saat menyampaikan pembelajaran, pendidik tidak hanya menggunakan metode konvesional yang dilakukan sehari-hari sehingga membuat siswa terkesan bosan saat pembelajaran selain itu pembelajaran konvensional mengakibatkan siswa sangat tergantung pada guru, dan hal ini dapat mengakibatkan proses pembelajaran kurang optimal (Romadiastri, 2017).Untuk mengatasi hambatan tersebut tentunya pendidik juga dapat mengenakan model pembelajaran inovatif dan kreatif dalam memadukan materi pembelajaran sehingga proses dari pembelajaran tersebut menjadi aktif sehingga siswa tidak jenuh saat pembelajaran berlangsung. Pada saat proses belajar mengajar tentu terapat banyak model pembelajaran aktif, inovatif, maupun juga kreatif sehingga dapat digunakan oleh guru dalam mengembangkan materi dan juga proses pembelajaran. Model pembelajaran pada dasarnya ialah sebuah pedoman/acuan bagi guru dalam merancang kegiatan pembelajaran yang cocok untuk mencapai tujuan pembelajaran dari materi/konsep yang akan dipelajari (Hardianto \& Baharuddin, 2019).Salah satu model pembelajaran yang dapat diterapkan dalam proses pembelajaran yaitu model pembelajaran PAIKEM dengan bermuatan nilai karakte.

Model pembelajaran inovatif yang bisa digunakan yaitu model pembelajaran PAIKEMsebuah pembelajaran yang memungkinkan peserta didik untuk mengerjakan kegiatan yang beragam dalam rangka mengembangkan keterampilan dan pemahamannya, dengan penekanan peserta didik belajar sambil bekerja, sementara guru menggunakan berbagai sumber dan alat bantu belajar (termasuk pemanfaatan lingkungan), supaya pembelajaran lebih menarik, menyenangkan dan efektif (Putu \& Dewi, 2020), . Hal ini juga di dukung oleh pendapat milik(Umi, 2016)yaitumodel pembelajaran PAIKEM bukan model pembelajaran baru. Sebelum model PAIKEM muncul, ada beberapa model pembelajaran lain yang telah terlebih dahulu muncul. Di antaranya adalah, model pembelajaran CBSA (cara belajar siswa aktif). Model ini telah lama populer di kalangan para guru. Kemudian inovasi pembelajaran terus menerus dilakukan dengan menambah sederetan model pembelajaran baru yang bernuansa baru, seperti PBL (Problem based Learning), Cooperatif Learning, CTL (Contextual Teaching Learning), dan sebagainya. Semua model pembelajaran tersebut mengarah pada pembelajaran yang tidak lagi menjadikan guru sebagai pusat belajar (teacher centered learning) karena ada asumsi bahwa pembelajaran yang terlalu didominasi oleh guru dapat menyebabkan peserta didik kurang aktif dan kreatif selama proses pembelajaran. Hal ini juga di dukung oleh pendapat milik (Umi, 2016). Dari pendapat tersebut dapat disimpulkan bahwa pembelajaran PAIKEM adalah model pembelajaran yang memungkinkan peserta didik untuk mengerjakan kegiatan yang beragam dalam rangka mengembangkan keterampilan dan pemahamannya, dengan penekanan peserta didik belajar sambil bekerja, sementara guru menggunakan berbagai sumber dan alat bantu belajar (termasuk pemanfaatan lingkungan), supaya pembelajran lebih menyenangkan dan efektif(Hayati \& Harianto, 2017).

Sintak model pembelajaran PAIKEM adalah (1) Menyampaikan tujuan dan memotivasi siwa, Guru menyampaikan semua tujuan pembelajaran yang ingin dicapai pada pelajaran tersebut dan memotivasi siswa belajar. (2)Menyajikan informasi, Guru menyajikan informasi kepada siswa dengan jalan demonstrasi atau lewat bahan bacaan. (3) Mengorganisasi siswa ke dalam kelompok-kelompok belajar, Guru menjelaskan kepada siswa bagaimana cara membentuk kelompok belajar dan membantu setiap agar melakukan transisi secara efisien. (4) Guru membimbing kelompok-kelompok belajar pada saat mereka mengerjakan tugas mereka. (5) Evaluasi, Guru mengevaluasi hasil belajar tentang materi yang telah dipelajari atau masing-masing kelompok mempresentasikan hasil kerjanya. (6) Memberikan penghargaan, Guru mencari cara-cara untuk menghargai baik upaya maupun hasil belajar individu dan kelompok(Umi, 2016).Dalam kegiatan pembelajaran dikelas untuk menunjang kelancaran dalam penyampaian suaut materi, guru dapat memadukan model pembelajaran PAIKEM dengan media pembelajaran. Media pembelajaran merupakan suatu komponen pembelajaran yang memiliki kaitan erat dan memiliki peran penting dalam menunjang keberhasilan suatu pembelajaran(Ananda, 2017). Bermacam media pembelajaran dapat dipadukan atau digunakan dalam proses penyampaian materi pada kegiatan pembelajaran namun disesuaikan terhadap materi yang dijelaskan, salah satunya yaitu media pembelajaran audio visual.Media belajar diakui sebagai salah satu faktor keberhasilan belajar. dengan media, peserta didik dapat termotivasi, terlibat aktif secara fisik maupun psikis, memaksimalkan seluruh indera peserta didik dalam belajar, dan menjadikan pembelajaran lebih bermakna(Fadhli, 2015).

Media pembelajaran dianggap penting karena dengan menggunakan media maka akanmemudahkan siswa dalam memahami materi karena dengan bantuan media dapat menyamakan persepsi siswa yang berbeda satu sama lain, mengkonkritkan konsep-konsep yang abstak, mampu menghadirkan objek-objek yang besar maupun berbahaya dalam pembelajaran di kelas, serta dapat memperlihatkan suatu proses tertentu yang terlalu cepat atau lambat dalam kerjanya. Dengan demikian adanya suatu media menjadi sangat penting dalam setiap pembelajaran. Maka media yang tepat yaitu aduio-visual(Lestari, 2017).(Ananda, 2017) menyatakan audio visual adalah media yang mampu 
menyajikan unsur suara (audio) serta gambar visual) secara beriringan dalam mengkomunikasikan informasi. Audio visual dilihat dar arti kata audio dan visual berarti media yang dapat didengar sekaligus dilihat (Hayati \& Harianto, 2017). Mitha (2014) menegaskan audio visual merupakan media perantara yang melibatkan pandangan serta pendengar yang mampu membuat suasana pembelajaran menjadi menarik.Penggunaan media audio visual yang dapat menaikan nilai peserta didik ini sesuaikan dengan yang disampaikan oleh Arsyad, Demikia pula penelitian Sediasih (2017), dan Yuliana, et al (2015), yang bahwa dengan media dapat memberikan sebagai berikut: 1) Pembelajaran lebih menarik perhatian peserta didik sehingga dapat menumbuhkan motivasi belajar; 2) Pembelajaran menjadi lebih jelas dan bermakna, sehingga dapat dipahami oleh peserta didik, 3) Peserta didik dalam kegiatan belajar, tidak hanya menyimak uraian guru saja, tetapi juga aktivitas lain seperti mengamati, melakukan, memerankan, dan mendemonstrasikan, dan 4) Model atau metode megajar akan lebih bervariasi, tidak hanya komunikasi verbal atau ceramah saja oleh guru, sehingga peserta didik tidak merasa jenuh, bosan, dan guru tidak kehabisan tenaga.ManfaatPenggunaan Media Audio Visual yaitu memperjelas penyajian pesan agar tidak terlalu bersifat verbalistis, mengatasi keterbatasan ruang, waktu dan daya indera, dengan menggunakan media pembelajaran secara tepat dan bervariasi dapat diatasi sikap pasif anak didik, dengan sifat yang unik pada setiap siswa, ditambah lagi dengan lingkungan dan pengalaman yang berbeda, sedangkan kurikulum dan materi pembelajaran ditentukan sama untuk setiap siswa, maka guru akan banyak mengalami kesulitan bilamana semuanya itu harus diatasi sendiri(Nomleni \& Manu, 2018).

Berdasarkan pemaparan diatas dapat dirangkum bahwa media audio visual adalah media perantara yang mengandung komponen suara dan gambar yang dapat dilihat dan didengarkan secara terpadu saat mengkomunikasikan informasi.Model pembelajaran PAIKEM berbantuan media audio visual yaitu sebuah model pembelajaran yang selalu mengangkat permasalahan yang memiliki konsep - konsep dimana didalamnya terdiri dari unsur sosial dan teknologi yang sedang berkembang disekitar kita seperti lingkungan, teknologi dan masyarakat, yang dimana penyampain informasinya melalui media perantara yang mengandung komponen suara dan gambar yang dapat dilihat dan didengarkan secara terpadu saat mengkomunikasikan informasi.

Dengan menerapkan model pembelajaran PAIKEM berbantuan media audio visual pembelajaran menjadi lebih efisien dan efektif sehingga mampu meningkatkan kompetensi pengetahuan IPS siswa.Kompetensi yaitu pengetahuan yang dimiliki oleh siswa dalam melaksanakan tugas dalam proses pembelajaran. Menurut (Nur, 2014) menyatakan bahwa kompetensi merupakan penguasaan suatu ilmu pengetahuan, bersikap, dan keterampilan sesuai dengan objek tertentu atau mata pelajaran yang sudah diajarkan. Sedangkan menurut (Baharudin, 2017)menyatakan bahwa kompetensi merupakan sesuatu yang sangat komplek karena ada banyak aspek yang harus diperhatikan didalamnya sehingga harus di pikirkan dangan matang. Salah satu aspek atau ranah itu ialah kompetensi pengetahuan dalam ranah kompetensi pengetahuan terdapat enam jenjang proses berpikir yaitu mengingat, memahami, menerapkan, menganalisis, mengevaluasi, dan mencipta. Keenam aspek ini biasanya digunakan untuk merumuskan tujuan pembelajaran yang dikenal dengan C1 sampai dengan C6.

Tujuan penelitian ini adalah untuk mengetahui pengaruh yang signifikan model pembelajaran PAIKEMberbantuan media audio visual terhadap kompetensi pengetahuan IPS kelas IV SD GugusPeliatan Tahun Ajaran 2019/2020.

\section{METODE PENELITIAN}

Jenis Penelitian ini dilaksanakan pada kelas IV SD Gugus peliatan dari bulan September 2019 sampai Maret 2020. Penelitian ini dilakukan dengan menerapkan pendekatan penelitian kuantitatif dengan desain eksperimental yaitu quasi experiment (Nonequilevalent Control Group Design). Pada desain nonequivalent control group design memiliki 2 kelompok sampel, yakni kelompok eksperimen dan kontrol. Ketika menentukan kedua kelompok, subjek atau partisipan penelitiannya tidak dipilih dengan cara acak, sehingga yang berperan sebagai kelompok eksperimen dan kontrol sudah dibentuk sebelumnya tanpa ada campur tangan dari peneliti dan tanpa dilaksanakan random individu karena kelas yang telah disusun oleh pihak sekolah tidak bisa diacak kembali .Pada desain ini, yang diperhitungkan adalah nilai posttest tanpa melihat nilai pretest karena tujuan dilakukannya penelitian hanya untuk dapat mengetahui perbedaan bukan peningkatan dari kompetensi pengetahuan matematika pada kelompok eksperimen yang di treatment dengan metode pembelajaran drill berbasis masalah kontekstual, sementara kelompok kontrol tidak di treatment dengan metode pembelajaran drill berbasis masalah kontekstual. Pemberian pretest kepada kedua kelompok untuk mengukur ekuivalensi atau penyetaraan kelompok. Uji-t digunakan dalam teknik penyetaraan kelompok. Selanjutnya agar mendapatkan data kompetensi pengetahuan matematika dari kedua kelompok menggunakan posttest. 
Jenis penelitian ini tergolong eksperimen semu (quasi experiment), menggunakan desain yaitu "Non-equivalent Control Group Design". Penelitian ini di lakukan di SD Negeri Gugus Peliatan yang terdiri dari 4 SD. Populasi pada penelitian ini terdapat 4 kelas dengan jumlah 146 siswa. Berikut distribusi banyaknya populasi. Penentuan sempel dalam penelitian ini menggunakan teknik random sampling. Adapun sempel dalam penelitian ini yaitu kelas IV SD Negeri 4 Peliatan sebagai kelompok eksperimen dan kelas IV SD Negeri 1Peliatan sebagai kelompok control. Variabel yang terdapat dalam penelitian ada 2 yaitu variabel bebas dan variabel terikat adapun variabel bebas dalam penelitain ini adalah model PAIKEM Berbantuan media Audio-visual dan variable terikat dalam penelitian ini adalah Kompetensi Pengetahuan IPS. Metode yang digunakan dalam pengumpulan data yakni dengan mengunakan metode tes pilihan ganda yang dimana sebelum metode ini digunakn sebagai alat untuk mengumpulkan data terlebih dahulu di lakukan pengujian validitas isi dan butir, uji daya beda, tingkat kesukaran dan reabilitas.Metode analisis data yang dipergunakan dalam penelitian ini yakni GnS yang diperoleh dari hasil Pretest maupun posttest. Setelah data GnS terkumpul langkah selanjutnya adalah melakukan uji Hipotesis dengan mengunakan uji t. sebelum dilakukan uji t terlebih dahulu melakukan uji prasyarat meliputi uji normalitas dan homogenitas.

Dari perhitungan uji normalitas sebaran data nilai pretest kelas IV SDN 4 Peliatan didapat nilai maksimum $\left|\mathrm{F}_{\mathrm{T}}-\mathrm{F}_{\mathrm{S}}\right|=0,214$ dan nilai tabel Kolmogorov-Smirnov untuk taraf signifikansi $5 \%=0,189$.

Karena nilai maksimum $\left|\mathrm{F}_{\mathrm{T}}-\mathrm{F}_{\mathrm{S}}\right|_{<}$nilai tabel Kolmogorov-Smirnov maka data berdistribusi normal.

Sedangkan perhitungan hasil uji normalitas nilai pretest kelas IV SDN 1Peliatan didapat $\left|\mathrm{F}_{\mathrm{T}}-\mathrm{F}_{\mathrm{S}}\right|=0,204$ dan nilai tabel Kolmogorov-Smirnov untuk taraf signifikansi $5 \%=0,191$. Karena nilai maksimum

$\left|\mathrm{F}_{\mathrm{T}}-\mathrm{F}_{\mathrm{S}}\right|_{<}$nilai tabel kolmogorov- smirnov, maka dinyatakan data berdistribusi normal. Setelah itu uji homogenitas dapat dilaksanakan karena kedua kelompok sudah berdistribusi normal. Dalam uji homogenitas nilai pretest kompetensi pengetahuan IPS siswa dilaksanakan dengan uji uji F. Dari uji homogenitas varians $\mathrm{F}_{\text {hit }}=0,963$ dan $\mathrm{F}_{\text {tab }}=1,779$ pada taraf signifikansi $5 \%$ dan dk $=66$. Ini berarti $\mathrm{F}_{\text {hit }}<$ $\mathrm{F}_{\text {tab }}$ sehingga hasil pretest sampel dikatakan homogen. Apabila data pretest kedua kelompok sudah normal dan homogen, selanjutnya dilaksanakan pengujian kesetaraan melalui uji-t. Dari hasil analisis diperoleh

$\mathrm{t}_{\text {hit }}=0,963$ dan $\mathrm{t}_{\mathrm{tab}}=1,779$ dengan taraf signifikansi $5 \%$ dan $\mathrm{dk}=32+36-2=66$. Berdasarkan uji$\mathrm{t}$ yang dilaksanakan diperoleh $\mathrm{t}_{\mathrm{hit}}=0,963<\mathrm{t}_{\mathrm{tab}}=1,779$ maka terjadi penerimaan $\mathrm{H}_{0}$ sehingga kedua kelompok dinyatakan setara. Setelah diketahui bahwa kedua kelompok benar-benar setara, maka selanjutnya diundi kembali agar dapat ditentukan sekolah yang berperan sebagai kelompok eksperimen dan kelompok kontrol. Berdasarkan hasil undi yang dilaksanakan diperoleh kelas IV SD Negeri 4 Peliatan berperan sebagai kelompok eksperimen dengan diberikan perlakuan menggunakan metode pembelajaran PAIKEMberbantuan media-audiovisual, sedangkan kelas IV SDN 1 Peliatan berperan sebagai kelompok kontrol dengan melaksanakan pembelajaran konvensional.

Untuk mengukur kompetensi pengetahuan IPS dalam penelitian ini mempergunakan tes objektif pilihan ganda. Tes ini meliputi empat option, yaitu a, b, c, atau d dengan pertanyaan sebanyak 30 butir soal. Skor 1 diberikan apabila siswa menjawab dengan benar dan skor 0 diberikan apabila siswa manjawab salah pada setiap butir soal. Skor dari masing-masing butir soal dijumlahkan kemudian jumlah itu menjadi skor variabel penguasaan kompetensi pengetahuan matematika yang bergerak dari kisaran nol (0) sampai dengan seratus (100). Nol (0) ialah skor minimum dan seratus (100) ialah skor maksimum tes penguasaan kompetensi pengetahuan matematika.

Kisi-Kisi dan Kurikulum merupakan validitas isi pada penelitian ini. Kompetensi pengetahuan IPS diukur dengan mempergunakan validitas butir tes objektif pilihan ganda biasa, melalui rumus koefisien korelasi point biserial $\left(\gamma_{\mathrm{pbi}}\right)$. Nilai yang didapatkan selanjutnya dibandingkan terhadap nilai yang didapat

dari $\mathrm{r}_{\mathrm{tab}}$, apabila $\mathrm{r}_{\text {hit }} \geq \mathrm{r}_{\mathrm{tab}}$, man dalam kategori valid. Akan tetapi bila $\mathrm{r}_{\text {hit }}<\mathrm{r}_{\mathrm{tab}}$, maka dalam

kategori tidak valid, dengan taraf signifikansi $5 \%$ dan $d k=n-2$. Pada kelas V SDN 4 Peliatan dilaksanakan uji coba instrument, dengan banyak siswa yang terlibat adalah 40 orang sehingga diperoleh

$\mathrm{r}_{\mathrm{tab}}=0,30$. Dari hasil uji validitas butir yang dilakukan, diperoleh 30 butir tes yang dinyatakan valid dan 10 butir tes tidak valid. 30 butir tes yang sudah valid kemudian dilakukan pengujian daya pembeda. Berdasarkan perhitungan uji daya beda tes didapat 7 butir tes dengan kriteria cukup, 17 butir tes baik dan 6 butir tes sangat baik. selanjutnya dilakukan pengujian indeks kesukaran. Berdasarkan perhitungan 
analisis indeks kesukaran didapatkan 7 butir tes termasuk kategori mudah, 19 butir tes sedang dan 5 butir tes sukar. Pengujian instrumen yang terakhir adalah uji reliabilitas. Hanya soal yang sudah valid saja bisa di uji reliabilitasnya. Rumus KR-20 dipergunakan untuk menentukan reliabilitas tes yang memiliki sifat dikotomi dan heterogen. Berdasarkan perhitungan uji reliabilitas terhadap 30 butir tes, maka diperoleh $r_{\mathrm{tt}}=0,89$. Berdasarkan hal tersebut, maka 0,89>0,70 yang berarti instrumen pada penelitian ini tergolong reliable.

Data kompetensi pengetahuan matematika yang digunakan adalah data hasil posttest yang diberikan setelah treatment. Data itu selanjutnya dianalisis mempergunakan metode analisis statistik. Pada teknik analisis data ada 2 jenis statistik yang dipergunakan, yakni analisis statistik deskriptif dan analisis statistik inferensial. Statistik deskriptif merupakan sejumlah metode yang berupaya menciptakan rangkuman dan description (gambaran) mengenai data yang diperoleh sesuai dengan kenyataan tanpa maksud menciptakan simpulan yang diterima secara umum (Sugiyono, 2018). Adapun data yang disajikan pada statistik deskriptif ialah perhitungan rata-rata (mean), standar deviasi dan varians. Maksud dari penggunaan statistik inferensial adalah untuk menguji hipotesis penelitian dengan teknik mengolah data dengan diterapkannya rumus statistik inferensial (Purwani et al., 2018). Dalam penelitian ini, sebelum dilaksanakan pengujian hipotesis, sebelumnya dilaksanakan pengujian prasyarat yakni uji normalitas dan homogenitas. Untuk bisa mengetahui apakan sebaran data sudah berdistribusi normal atau tidak maka dilaksanakan pengujian normalitas. Setelah itu barulah bisa ditentukan teknik yang digunakan untuk menganalisis data. Teknik yang terpilih untuk menganalisis data agar diketahui kenormalan sebaran data yakni dengan uji kolmogorov-smirnov. Kriteria pengujian pada taraf signifikansi 5\% jika harga nilai maksimum $\left|\mathrm{F}_{\mathrm{r}}-\mathrm{F}_{\mathrm{g}}\right| \leq$ harga tabel Kolmogoriv-smirnov, maka terjadi penerimaan $\mathrm{H}_{0}$ dan data berdistribusi normal. Apabila kenormalan data sudah diuji, selanjutnya dilaksanakan pengujian homogenitas agar uji prasyarat dapat terpenuhi dan dapat dibuktikan bahwa perbedaan dalam uji hipotesis disebabkan karena perbedaan variansi, bukan karena perbedaan antar kelompok. Uji homogenitas varians dilakukan dengan uji fisher (uji F). Kriteria pengujian, yakni apabila harga $\mathrm{F}_{\text {hit }}<\mathrm{F}_{\text {tab }}$, maka data homogen. Dengan pengujian pada taraf signifikansi $5 \%$ dan $\mathrm{dk}$ pembilang $=\mathrm{n} 1-1_{\mathrm{dan}} \mathrm{dk}$ penyebut $=\mathrm{n} 2-1$. Uji beda mean (uji $\mathrm{t}$ ) dengan rumus polled varians dipergunakan untuk menganalisis data, dengan kriteria yaitu apabila harga $t_{\text {hit }} \leq t_{\text {tab }}$ maka yang terjadi adalah diterimanya $\mathrm{H}_{0}$ dan ditolaknya $\mathrm{Ha}$. Sedangkan apabila harga $\mathrm{t}_{\text {hit }}>\mathrm{t}_{\text {tab }}$ maka yang terjadi adalah ditolaknya $\mathrm{H}_{0}$ dan diterimanya $\mathrm{H}_{\mathrm{a}}$. Pada taraf signifikansi $5 \%$ dan $\mathrm{dk}=\mathrm{n} 1+\mathrm{n} 2-2$.

\section{ANALISIS DAN PEMBAHASAN}

Pembelajaran yang terlaksana di dalam kelas selama penelitian secara umum telah berjalan sesuai dengan rencana pembelajaran dengan mempergunakan model pembelajaran PAIKEMberbantuan audiovisual. Deskripsi data yang dipaparkan dalam penelitian ini yaitu hasil posttest dari kelompok eksperimen dan kelompok kontrol di SD gugus Peliatan Tahun Ajaran 2019/2020. Data yang diperoleh pada penelitian ini digolongkan menjadi dua, yakni data kompetensi pengetahuan IPS kelompok eksperimen di SDN 4 Peliatan dan data kompetensi pengetahuan IPS kelompok kontrol di SDN 1Peliatan.

Untuk dapat melaksanakan uji hipotesis penelitian kedua kelompok terlebih dahulu harus melewati uji prasyarat yang meliputi uji normalitas sebaran data dan uji homogenitas varians. Kriteria pengujian

hipotesis yakni jika harga $\mathrm{t}_{\text {hit }} \leq \mathrm{t}_{\mathrm{tab}}$ maka terjadi penerimaan $\mathrm{H}_{0}$ dan penolakan Ha. Sedangkan jika harga

$\mathrm{t}_{\text {hit }}>\mathrm{t}_{\mathrm{tab}}$ maka terjadi penolakan $\mathrm{H}_{0}$ dan penerimaan $\mathrm{H}_{\mathrm{a}}$. Pada taraf signifikansi $5 \%$ dan $\mathrm{dk}=\mathrm{n} 1+\mathrm{n} 2-2$. Karena data kelompok eksperimen dan kontrol dinyatakan telah berdistribusi normal dan homogen, maka pengujian hipotesis data kompetensi pengetahuan IPS mempergunakan statitik parametrik melalui rumus uji-t polled varians. Berikut ialah hipotesis yang akan diajukan.

$\mathrm{H}_{0}$ : tidak terdapat perbedaan yang signifikan kompetensi pengetahuan IPS kelompok siswa yang dibelajarkan menggunakan model pembelajaran drill berbasis masalah kontekstual dan kompetensi pengetahuan IPS kelompok siswa yang dibelajarkan menggunakan pembelajaran konvensional pada kelas IV SD Gugus Moh. Hatta Denpasar Selatan tahun ajaran 2019/2020.

Hipotesis statistiknya adalah sebagai berikut.

$H_{0}: \mu 1=\mu 2$

Penjelas : 
$\mu 1$ = rata-rata kompetensi pengetahuan IPS siswa menggunakan model pembelajaran PAIKEM berbantuan audio-visual. $\mu 2$ = rata-rata kompetensi pengetahuan IPS siswa menggunakan pembelajaran konvensional

Berdasarkan hasil uji normalitas kelompok eksperimen didapat nilai maksimum $=0,699$ dan nilai

tabel Kolmogorov-Smirnov untuk taraf signifikansi $5 \%=0,234$ karena nilai maksimum $\quad\left|\mathrm{F}_{\mathrm{T}}-\mathrm{F}_{\mathrm{S}}\right|_{<\text {nilai }}$ tabel Kolmogorov-Smirnov maka data berdistribusi normal. Sedangkan hasil uji normalitas kelompok

kontrol didapat nilai maksimum $=0,227$ dan nilai tabel Kolmogorov-Smirnov untuk taraf

signifikansi $5 \%=0,227$ karena nilai maksimum $\left|\mathrm{F}_{\mathrm{T}}-\mathrm{F}_{\mathrm{S}}\right|_{<}$nilai tabel Kolmogorov-Smirnov maka data berdistribusi normal. Adapun hasil pengujian normalitas kelompok eksperimen dan kontrol disajikan dalam bentuk Tabel berikut.

Tabel 1. Rekapitulasi Hasil Uji Normalitas Sebaran Data Gain skor

\begin{tabular}{llllll}
\hline No & Anggota Populasi & Nilai Maksimum & Nilai Tabel & Kolmogorof -Smirnov & Keterangan \\
\hline 1 & Kelompok Eksperimen & 0,699 & 0,234 & 0,277 & Normal \\
2 & Kelompok Kontrol & 0,125 & & & \\
\hline
\end{tabular}

Setelah data kedua kelompok dinyatakan normal selanjutnya dilakukan pengujian homogenitas dan diperoleh nilai $\mathrm{F}_{\text {hit }}=0,963$ dan nilai $\mathrm{F}_{\mathrm{tab}}=1,779$ pada taraf signifikansi $5 \%$ dan dk pembilang $=35$ serta dk penyebut $=31$. Karena $\mathrm{F}_{\text {hit }}=0,963<\mathrm{F}_{\mathrm{tab}}=1,779$ maka varians kedua kelompok homogen. Adapun hasil pengujian normalitas kelompok eksperimen dan kontrol disajikan dalam bentuk Tabel berikut.

Tabel 2. Rekapitulasi Hasil Uji Homogenitas Varians Data Post Test

\begin{tabular}{|c|c|c|c|c|c|c|}
\hline No & Anggota Populasi & $s_{1}^{2} s_{2}^{2}$ & $\mathrm{Dk}$ & $F_{\text {hitung }}$ & $\mathrm{F}_{\text {tabel }}$ & Simpulan \\
\hline 1 & Kelompok Eksperimen & 0,021 & 77 & 0,963 & 1,779 & Homogen \\
\hline 2 & Kelompok Kontrol & 0,020 & & & & \\
\hline
\end{tabular}

Dari uji prasyarat yang dilaksanakan didapatkan data kedua kelompok telah berdistribusi normal dan homogen. Selanjutnya dilaksanakan uji statistik dengan mempergunakan uji beda mean (uji-t) dengan rumus Polled Varians. Rekapitulasi hasil uji beda mean (uji-t) ada pada tabel 3.

Tabel 3. Rekapitulasi Hasil Uji-t

\begin{tabular}{|c|c|c|c|c|c|c|c|c|}
\hline No & Kelompok & Rerata & $S^{2}$ & $\mathbf{N}$ & DK & $t_{\text {hit }}$ & $t_{\text {tab }}$ & ulan \\
\hline 1 & Eksperimen & 13,688 & 1,189 & 32 & 66 & 0,130 & 1,996 & $\mathrm{H}_{0}$ ditolak \\
\hline 2 & Kontrol & 13,722 & & & & & & \\
\hline
\end{tabular}

Dari tabel tersebut menunjukan $\mathrm{t}_{\text {hit }}=0,130$ dan $\mathrm{t}_{\mathrm{tab}}=1,996$ untuk $\mathrm{dk}=\mathrm{n}_{1}+\mathrm{n}_{2}-2=66$ dengan taraf signifikansi $5 \%$. Dengan begitu bisa dikatakan terjadi penolakan $\mathrm{H}_{0}$ dan penerimaan $\mathrm{H}_{a}$ dikarenakan $t_{\text {hit }}>t_{\text {tab }}$. Ini artinya terdapat perbedaan yang signifikan kompetensi pengetahuan IPS antara kelompok yang dibelajarkan dengan menggunakan model pembelajaran PAIKEMberbantuan media Audio-visual dan kelompok yang dibelajarkan dengan menggunakan pembelajaran konvensional pada kelas IV SD Gugus Peliatan tahun ajaran 2019/2020.

Rata-rata kompetensi pengetahuan IPS kelompok eksperimen $\overline{\mathrm{X}}=13,688$ dan kelompok kontrol $\overline{\mathrm{X}}=13,722$. Hal tersebut menunjukan bahwa nilai rata-rata kelompok eksperimen $\overline{\mathrm{X}}=13,688>\overline{\mathrm{X}}=13,722$ kelompok kontrol. Setelah dikonversikan ke dalam PAP skala 5 didapatkan analisis kompetensi pengetahuan IPS pada kelompok eksperimen 13,688 yaitu tingkat kemampuan siswa termasuk baik. Hal tersebut dikarenakan model pembelajaran PAIKEMberbantuan audio-visual yang diberikan kepada kelompok eksperimen merupakan suatu inovasi dalam pembelajaran yang menekankan 
kreativitas dan keterampilan seorang guru di dalam menyusun suatu pembelajaran yang atraktif dan menggembirakan pada kegiatan pembelajaran dengan begitu pembelajaran akan bermakna dan berarti bagi siswa serta materi pelajaran mudah dimengerti. Model ini juga memberi pengalaman kepada siswa di dalam menuntaskan permasalahan yang memiliki kaitan dengan kehidupan sehari-harinya sehingga ia terampil menyelesaikan permasalahan yang ditemui dalam pembelajaran ataupun pada kehidupan sehari-harinya. Belajar untuk memecahkan permasalahan merupakan prinsip dasar pada pembelajaran IPS. Selain itu model ini juga melatih keterampilan dan ketangkasan siswa ketika menjawab soal melalui kegiatan latihan yang dilatihkan oleh guru. Latihan yang dilakukan secara praktis, mudah untuk dilakukan, dan melaksanakannya secara teratur membina siswa untuk menambah penguasaan keterampilan itu bahkan dengan sempurna. Hal tersebut mampu menunjang prestasi siswa di bidang pembelajaran. Sedangkan nilai rata-rata pada kelompok kontrol 13,722 yaitu tingkat kemampuan siswa termasuk kategori cukup baik. Keadaan tersebut dikarenakan dalam proses belajar mengajar segala sesuatunya sebagian besar didominasi oleh guru, sehingga siswa masih kesulitan untuk mengingat dan memahami sesuatu yang mereka terima, karena mereka tidak mengalaminya dan tidak berperan didalamnya. Selain itu mereka juga kurang melakukan latihan-latihan soal yang memiliki kaitan dengan materi pelajaran. Adapun tabel nilai rata-rata kompetensi pengetahuan IPS kelompok eksperimen dan kontrol disajikan dalam bentuk tabel berikut.

Tabel 4. Nilai Rata-rata Kompetensi Pengetahuan IPS Kelompok Eksperimen dan Kontrol

\begin{tabular}{llll}
\hline No & Anggota Populasi & Nilai Rata-rata & Keterangan \\
\hline 1 & Kelompok Eksperimen & 13,688 & Baik \\
2 & Kelompok Kontrol & 13,722 & Cukup Baik \\
\hline
\end{tabular}

Berdasarkan perolehan nilai kompetensi pengetahuan IPS pada kedua kelompok, dapat diketahui awalnya kedua kelompok telah memunyai kemampuan yang setara. Setelah kelompok eksperimen diberikan treatment, perolehan nilai kompetensi pengetahuan IPS kedua kelompok mengalami perbedaan. Kompetensi pengetahuan IPS kelompok eksperimen lebih besar dibandingkan kompetensi pengetahuan IPS kelompok kontrol. Kondisi ini merupakan akibat dari pemberian treatment kepada kelompok eksperimen, yaitu berupa model pembelajaran PAIKEM berbantuan audio-visual.

Pada model pembelajaran PAIKEM menggunakan media audio-visual juga dapat berdampak positik karena memungkinkan siswa melakukan kegiatan yang beragam untuk mengembangkan sikap, pemahaman, dan keterampilannya sendiri(Hanifah, 2016) .Secara garis besar, model pembelajara PAIKEM berdapak pada kompetensi IPS karena ada Siswa terlibat dalam berbagai kegiatan yang mengembangkan pemahaman dan kemampuan mereka dengan penekanan pada belajar melalui perbuat. Penelitian pada model paikem di perkuat dengan adanya peneliti penelitian yang dilakukan oleh Dewi (2017) tentang pengaruh model SETS bebantuan media audio-visual terhadap kompetensi pengetahuan IPS kelas IV SD Gugus Kolonel I Gusti Ngurah Rai Denpasar Utara. dengan hasil penelitian menunjukan antara peserta didik yang mengikuti pembelajaran dengan model PAIKEM berbantuan audio-visual dengan peserta didik dikarenakan $t_{\text {hitung }}>t_{\text {tabel }}(4,950>1,989)$ serta terdapat perbedaan rata-rata kelompok yang dibelajarkan dengan menggunakan model PAIKEM berbantuan media audio-visual yaitu 81,09 lebih dari rata - rata kelompok yang dibelajarkan menggunakan pembelajaran Konvensional yaitu 67,13. Persamaan penelitian tersebut dengan penelitian ini yaitu berbantuan media audio-visual dan variabel terikat yaitu kompetensi pengetahuan IPS Adapun perbedaan penelitian ini terletak pada variabel bebas. Variabel bebas pada penelitian tersebut adalah model PAIKEM .

Kegiatan pembelajaran di kelas eksperimen dengan model pembelajaran PAIKEM berbantuan media audio-visual terlaksana dengan baik, kondusif serta optimal. Model pembelajaran PAIKEM berbantuan media audio-visual ialah kegiatan pembelajaran yang dilaksanakan dengan melakukan latihan secara berulang-ulang dengan menghadapkan siswa pada suatu media audio yang dikaitkan dengan kehidupan nyatanya, sehingga kegiatan pembelajaran menjadi menyenangkan, bermakna serta mudah untuk dapat dimengerti oleh siswa. Berbeda pada kelompok kontrol, dengan pembelajaran konvensional sebagaimana biasa diterapkan pada kelompok kontrol. Dalam proses belajar mengajar segala sesuatunya sebagian besar didominasi oleh guru, sehingga siswa masih kesulitan untuk mengingat dan memahami sesuatu yang mereka terima, karena mereka tidak mengalaminya dan tidak berperan didalamnya. Selain itu mereka juga kurang melakukan latihan-latihan soal yang memiliki kaitan dengan materi pelajaran.

Pada penelitian ini dapat memberikan implikasi terhadap pembelajaran di sekolah dasar. Implikasi secara teoritis penggunaan model pembelajaran yang sesuai dengan kompetensi mampu mempengaruhi rasa antusias, keaktifan, kreativitas dan pencapaian kompetensi pengetahuan siswa. Untuk pelajaran IPS, terdapat perbedaan antara kompetensi pengetahuan IPS siswa yang dibelajarkan dengan model 
PAIKEMberbantuan audio-visual dengan kompetensi IPS siswa yang dibelajarkan dengan pembelajaran konvensional. Sedangkan impikasi secara praktis hasil dari penelitian ini dipergunakan untuk bahan pertimbangan kepada guru dan calon guru. Hal yang dapat dilakukan adalah dengan membenahi dan meningkatkan kemampuan diri sehubung dengan pembelajaran yang telah dilakukan dan kompetensi pengetahuan yang sudah dicapai dengan memperhatikan model pembelajaran yang sesuai dengan memvariasikan beberapa model pembelajaran agar bisa meningkatkan kompetensi pengetahuan IPS siswa menjadi lebih baik. Jadi dapat diambil kesimpulan model pembelajaran PAIKEMberbantuan media audio-visual berpengaruh secara signifikan terhadap kompetensi pengetahuan IPS kelas IV SD Gugus Peliatan tahun ajaran 2019/2020.

\section{KESIMPULAN}

Berdasarkan hasil pengujian hipotesis dan pembahasan, maka diperoleh analisis uji-t diperoleh $t_{\text {hit }}$ $=0,916$ sedangkan pada taraf alpha $0,05 \mathrm{dan} \mathrm{dk}=70$ diperoleh nilai $\mathrm{t}_{\mathrm{tab}}=1,996$. Oleh karena $t_{\text {hit }}=0,916>$ $t_{\text {tab }}=1,99$ maka H0 ditolak Ini berarti terdapat perbedaan yang signifikan kompetensi pengetahuan IPS antara kelompok yang dibelajarkan menggunakan model pembelajaran PAIKEMdengan kelompok yang dipelajarkan menggunakan pembelajaran konvensional. Rerata GnS kelompok eksperimen sebesar 0,699 dan rerata GnS kelompok kontrol sebesar 0,534. Jadi dapat disimpulkan bahwa model pembelajaran PAIKEMberbantuan media audio-visual berpengaruh secara signifikan terhadap kompetensi pengetahuan IPS Kelas IV SD Negeri Gugus Peliatan Tahun Ajaran 2019/2020.Adapun saran yang dapat disampaikan sebagai berikut : Kepada siswa hendaknya mengikuti kegiatan pembelajaran dengan baik agar dapat meningkatkan kompetensi pengetahuan IPS.Saran kepada guru-guru di sekolah dasar dapat menerapkan pembelajaran dengan model pembelajaran PAIKEMberbantuan media audio-visual sesuai dengan sintaks agar dapat meningkatkan kompetensi pengetahuan IPS siswa.Saran kepada Kepala Sekolah hasil penelitian ini dapat dijadikan bahan kebijakan dalam meningkatkan kualitas pembelajaran IPS yang dilaksanakan oleh guru-guru dan dapat memfasilitasi segala aktivitas belajar siswa .Saran kepada peneliti lain dapat mengembangkan model penelitian ini dan mengaitkannya dengan mata pelajaran lain, sehingga nantinya dapat menambah ilmu pengetahuan.

\section{DAFTAR PUSTAKA}

Ananda, R. (2017). Penggunaan Media Audio Visual Untuk Meningkatkan Hasil Belajar Pendidikan Kewarganegaraan Siswa Kelas Iv Sd Negeri 016 Bangkinang Kota. Jurnal Basicedu, 1(1), 21-30. Https://Doi.Org/10.31004/Basicedu.V1i1.149

Baharudin, H. (2017). Peningkatan Kompetensi Guru Melalui Sistem Kepemimpinan Kepala Madrasah. Jurnal Ilmu Tarbiyah At-Tajdid, 6(1), 1-26.

Fadhli, M. (2015). Pengembangan Media Pembelajaran Berbasis Video Kelas Iv Sekolah Dasar. Jurnal Dimensi Pendidikan Dan Pembelajaran, 3(1), 24-29. Https://Doi.Org/10.24269/Dpp.V3i1.157

Hanifah, U. (2016). Penerapan Model Paikem Dengan Menggunakan Media Permainan Bahasa Dalam Pembelajaran Bahasa Arab. Ilmu Tarbiyah “At-Tajdid," 5(2), 301-330.

Hardianto, H., \& Baharuddin, M. R. (2019). Efektifitas Penerapan Model Pembelajaran Paikem Gembrot Terhadap Peningkatan Hasil Belajar Mahasiswa Pada Mata Kuliah Pembelajaran Matematika Sekolah Dasar. Cokroaminoto Journal of Primary Education, 2(1), 27-33. Https://Doi.Org/10.30605/Cjpe.212019.105

Hayati, N., \& Harianto, F. (2017). Hubungan Penggunaan Media Pembelajaran Audio Visual Dengan Minat Peserta Didik Pada Pembelajaran Pendidikan Agama Islam Di Sman 1 Bangkinang Kota. Al-Hikmah: Jurnal Agama Dan Ilmu Pengetahuan, 14(2), 160-180. Https://Doi.Org/10.25299/AlHikmah:Jaip.2017.Vol14(2).1027

Lestari, A. (2017). Keefektifan Media Audio Visual Sebagai Kreativitas Guru Sekolah Dasar Dalam Menumbuhkan Keterampilan Menulis Puisi Siswa. Scholaria: Jurnal Pendidikan Dan Kebudayaan, 7(3), 214. Https://Doi.Org/10.24246/J.Scholaria.2017.V7.I3.P214-225 
Nomleni, F. T., \& Manu, T. S. N. (2018). Pengembangan Media Audio Visual Dan Alat Peraga Dalam Meningkatkan Pemahaman Konsep Dan Pemecahan Masalah. Scholaria: Jurnal Pendidikan Dan Kebudayaan, 8(3), 219-230. Https://Doi.Org/10.24246/J.Js.2018.V8.I3.P219-230

Nur, A. A. (2014). Meningkatkan Kompetensi Pedagogik Guru Di Sd. Jurnal Administrasi Pendidikan, 2(1), 65-72.

Purwani, N. P. R., Darsana, I. W., \& Manuaba, I. B. S. (2018). Pengaruh Model Pembelajaran Picture And Picture Berbasis Karakter Terhadap Kompetensi Pengetahuan Ips. Journal For Lesson And Learning Studies, 1(2), 165-172. Https://Doi.Org/10.23887/Jlls.V1i2.14714

Putu, N., \& Dewi, J. (2020). Metode Pembelajaran Drill Berbasis Masalah Kontekstual Terhadap Kompetensi Pengetahuan Matematika. Mimbar Pgsd Undiksha, 8(2).

Rina Febriani, Zaitul, A. (2019). Vol. 1 No.4 Edisi 2 Juli 2019 Http://Jurnal.Ensiklopediaku.Org Ensiklopedia Of Journal. 1(4), 153-157.

Romadiastri, Y. (2017). Meningkatkan Kemampuan Penguasaan Konsep Dan Metode Pembelajaran Matematika Dengan Paikem Berbasis Ict Bagi Guru Madrasah Ibtidaiyah (Mi). At-Taqaddum, 8(2), 210. Https://Doi.Org/10.21580/At.V8i2.1171

Susanto, A. (2013). Teori Belajar Dan Pembelajaran Di Sekolah Dasar Edisi Kedua. Jakarta: Prenamedia Group.

Umi. (2016). Penerapan Model Paikem Dengan Menggunakan Media Permainan Bahasa Dalam Pembelajaran Bahasa Arab. Ilmu Tarbiyah “At-Tajdid,” 5(2), 301-330. 